\title{
Effects of cyanobacterial allelochemicals on a natural plankton community
}

\author{
Sanna Suikkanen ${ }^{1, *}$, Giovana O. Fistarol ${ }^{2,3}$, Edna Granéli ${ }^{2}$ \\ ${ }^{1}$ Finnish Institute of Marine Research, PO Box 33, 00931 Helsinki, Finland \\ ${ }^{2}$ Department of Marine Sciences, University of Kalmar, Landgången 3, 39231 Kalmar, Sweden \\ ${ }^{3}$ Present address: LabTox., Dept. de Engenharia Sanitária e Ambiental, Centro Tecnológico da UFSC, Campus Universitário \\ Trinidade, Florianópolis, Santa Catarina, CEP 88040-900, Brazil
}

\begin{abstract}
We investigated the effects of cell-free filtrates of the cyanobacteria Nodularia spumigena, Aphanizomenon sp. and Anabaena sp. on a brackish-water plankton community $(<150 \mu \mathrm{m})$. In a laboratory experiment, we monitored the concentration of chlorophyll $a$ and cell numbers of bacteria, phytoplankton and ciliates in the experimental units treated with cyanobacterial filtrates and the control medium. Cyanobacterial filtrates altered the cell numbers of many phytoplankton groups; they stimulated both colonial (Snowella spp.) and filamentous cyanobacteria (Pseudanabaena spp., Anabaena spp., Aphanizomenon sp., N. spumigena), a chlorophyte (Oocystis sp.), a dinoflagellate (Amphidinium sp.) and nanoflagellates, but inhibited cryptophytes. The filtrates also increased the numbers of bacteria at the beginning of the experiment, whereas they had no effect on ciliate abundances. Our results suggest that cyanobacteria may enhance the effects of eutrophication by stimulating various phytoplankton groups. The specific compounds causing this stimulation remain to be studied. On the other hand, cyanobacteria also seem able to reduce the biomass of certain phytoplankton species, via an allelopathic mechanism.
\end{abstract}

KEY WORDS: Cyanobacteria $\cdot$ Nodularia $\cdot$ Aphanizomenon $\cdot$ Anabaena $\cdot$ Allelopathy $\cdot$ Baltic Sea

\section{INTRODUCTION}

Mass occurrences of phytoplankton may have various implications for the surrounding ecosystem. In the Baltic Sea, late-summer blooms formed by the cyanobacteria Nodularia spumigena, Aphanizomenon sp. and Anabaena spp. are recurrent phenomena, but they have intensified during recent decades, most probably due to eutrophication (Kahru et al. 1994, Finni et al. 2001). The capacity of cyanobacteria to affect other aquatic organisms, such as viruses, bacteria, fungi, phytoplankton, zooplankton and fish, has been demonstrated in various laboratory studies (reviewed by Landsberg 2002). The increasing cyanobacterial blooms might, thus, be changing the structure of the aquatic communities in the Baltic Sea.

Allelopathy refers to inhibitory as well as stimulatory biochemical effects of one plant or microorganism on another (Rice 1986). Allelopathic interactions are widespread, occurring in all aquatic habitats and among all groups of aquatic primary producers (Gross 2003). In cyanobacteria, allelopathy seems to be especially common in freshwater species (Gross 2003), but there is also recent evidence on allelopathic inhibition of cryptophyte and diatom growth by brackish-water cyanobacteria (Suikkanen et al. 2004). It has been suggested that the ecological role of allelochemicals in Baltic Sea cyanobacteria is to maintain their dominance, after a critical cell concentration has been formed due to environmental factors (Suikkanen et al. 2004).

As most studies concerning allelopathy have been conducted in the laboratory with single, isolated species pairs, there is a dearth of studies on the role of allelopathy in natural plankton communities (Legrand et al. 2003). Combining laboratory and field studies by 
employing meso- or microcosm experiments with natural phytoplankton communities may provide more reliable data on the actual effects of potentially allelopathic species on the plankton assemblages. While there are studies on cyanobacterial effects on natural aquatic communities, they have usually focused on the effects of cyanobacterial toxins (Lindholm et al. 1992, Christoffersen 1996 and references therein). In a mesocosm experiment, Engström-Öst et al. (2002) monitored the effects of decaying filaments of Nodularia spumigena on a natural plankton assemblage, and found no direct harmful effects of the cyanobacteria on microorganisms. However, cell-free filtrates should be used to distinguish the possible allelopathic effects, caused by cyanobacterial exudates and not by direct cell contact, from those of interspecific nutrient competition.

In this study, we tested the hypothesis that Nodularia spumigena, Aphanizomenon sp. and Anabaena sp. are able to produce allelochemicals that affect natural plankton communities. To do this, we studied the effects of cell-free filtrates of the 3 cyanobacteria on a $<150 \mu \mathrm{m}$ plankton community. Special emphasis was given to effects on phytoplankton, although the numbers of bacteria and ciliates were also monitored. The aim was to find out how cyanobacteria affect the abundance of the different parts of a microplankton community, and the species composition of phytoplankton.

\section{MATERIALS AND METHODS}

Sampling. A water sample was taken with a submersible pump from $6 \mathrm{~m}$ depth from an open sea area in the southern Baltic Proper $\left(56^{\circ} 55^{\prime} 80^{\prime \prime} \mathrm{N}\right.$, $17^{\circ} 00^{\prime} 64^{\prime \prime} \mathrm{E}_{\text {; depth }} 32 \mathrm{~m}$ ) on 29 July 2002 . At the sampling depth, the water temperature was $14.4^{\circ} \mathrm{C}$ and the salinity $6.7 \mathrm{psu}$. The sample was filtered through a $150 \mu \mathrm{m}$ mesh nylon net to remove mesozooplankton, and transported to the laboratory of the University of Kalmar, Sweden.

Cyanobacterial cultures. Three cyanobacterial species were tested for their effects on the natural plankton community. The strains of Nodularia spumigena (KAC 13) and Anabaena sp. (cf. lemmermannii; KAC 16) originated from the Kalmar Algal Collection (KAC), University of Kalmar, Sweden, whereas Aphanizomenon sp. (Tr183) was obtained from Prof. K. Sivonen, University of Helsinki, Finland. All cyanobacterial strains were originally isolated from the Baltic Sea. The $N$. spumigena strain produces a toxin, nodularin, whereas the Anabaena and the Aphanizomenon sp. strains have been reported as non-toxic (Lehtimäki et al. 1997, Lyra et al. 2001). Based on a toxin analysis performed shortly before the experiments, the N. spu- migena culture filtrate contained $28.7 \mathrm{ng}$ nodularin equivalents $(\mu \mathrm{g} \mathrm{chl} \mathrm{a)})^{-1}$ (Suikkanen et al. 2004). The strains were grown in $\mathrm{f} / 10$ medium (Guillard 1975) at $15^{\circ} \mathrm{C}, \sim 20 \mu \mathrm{E} \mathrm{m} \mathrm{m}^{-2} \mathrm{~s}^{-1}$, under a light:dark regime of 18:6 $\mathrm{h}$, and continuously supplied with air. The culture medium was prepared from filtered seawater (Whatman GF/C) and its salinity was adjusted to $6.8 \mathrm{psu}$. The culture biomass was monitored by chlorophyll a measurements to confirm exponential growth of the cyanobacterial species at the beginning of the experiment. Prior to the experiment, the concentrations of major inorganic nutrients (nitrate, $\mathrm{NO}_{3}-\mathrm{N}_{i}$ ammonium, $\mathrm{NH}_{4}-\mathrm{N}_{;}$and phosphate, $\mathrm{PO}_{4}-\mathrm{P}$ ) were determined in the cyanobacterial cultures.

Experimental design. The effects of the 3 cyanobacterial species were tested by exposing the natural plankton community to cell-free filtrates of the cyanobacterial cultures. The filtrates were obtained by gently filtering (with a pressure lower than $-2 \mathrm{kPa}$ ) $120 \mathrm{ml}$ aliquots of the cyanobacterial cultures with ca. $250 \mu \mathrm{g}$ chl a $1^{-1}$, through GF/C filters. Freshly prepared filtrates were added to triplicate 11 Erlenmeyer flasks containing $280 \mathrm{ml}$ of the natural community, to make a total volume of $400 \mathrm{ml}$, which thus corresponded to ca. $75 \mu \mathrm{g} \mathrm{chl} \mathrm{a} \mathrm{l}^{-1}$ of cyanobacteria. Triplicate controls were prepared by adding $120 \mathrm{ml}$ of $\mathrm{f} / 20$ growth medium (Guillard 1975) to the plankton community. Nitrate and phosphate concentrations in all cyanobacterial filtrates were adjusted to the same level, close to the nutrient concentrations in $f / 20$ growth medium. Nutrient adjustments were performed to assure that the same amounts of nitrate and phosphate were added to both the filtrate treatments and the controls.

The experimental flasks were incubated in a culture room at $15^{\circ} \mathrm{C}, \sim 20 \mu \mathrm{E} \mathrm{m}^{-2} \mathrm{~s}^{-1}$, under a light:dark regime of $18: 6 \mathrm{~h}$, the conditions resembling those during the sampling occasion. On each day of the $4 \mathrm{~d}$ (96 h) experiment, $120 \mathrm{ml}$ of the test volume was removed and replaced with corresponding volumes of fresh cyanobacterial filtrates or control solution. The effects of the cyanobacterial filtrates on the natural plankton community were assessed by comparing the cell numbers of bacteria, phytoplankton and ciliates, and chlorophyll a concentrations in the filtrate treatments and the control. Chlorophyll a concentration, as well as the numbers of bacteria and ciliates, were determined daily from the removed volume, whereas phytoplankton cells were counted on the first and last days of the experiment.

Analyses. The concentrations of inorganic nutrients in the cyanobacterial cultures were determined prior to the experiment according to Valderrama (1995).

For chlorophyll $a$ analysis of the cyanobacterial cultures prior to the experiment, triplicate $5 \mathrm{ml}$ samples were filtered on GF/C filters and the cyanobacterial 
cells were extracted in 90\% methanol (MacKinney 1941). The chlorophyll a fluorescence of the samples was read with a TD-700 fluorometer (Turner Designs). During the experiments, the chlorophyll a concentration in the natural community was monitored by filtering $70 \mathrm{ml}$ samples and extracting them in $95 \%$ ethanol (Jespersen \& Christoffersen 1987), and measured as described above.

Bacterial abundance was estimated using a FACSCaliburTM flow cytometer (Becton Dickinson) equipped with an argon laser (excitation $488 \mathrm{~nm}$ ), according to del Giorgio et al. (1996). Before flow cytometer counts, bacteria samples were preserved with $37 \%$ formaldehyde ( $1 \%$ final concentration) and aliquots of $1 \mathrm{ml}$ were stained with the DNA dye, SYTO $13(2 \mu \mathrm{M}$ final concentration) for 10 to $15 \mathrm{~min}$ at room temperature in the dark. The green fluorescence signal of SYTO 13-stained bacterial cells was collected through a 530/30 band pass filter (FL-1) and plotted against forward light scatter (FSC, 488/10 band pass filter) in a dual parameter dot plot with both parameters having a logarithmic scale. Samples were run in low flow mode, and the flow was precisely calculated using a solution with a known amount of fluorescent beads (TruCount $^{\mathrm{TM}}$, Becton Dickinson). Both data acquisition and analysis were performed using the software CellQuest $^{\mathrm{TM}}$ (Becton Dickinson).

Phytoplankton and ciliates were determined from $40 \mathrm{ml}$ samples preserved with acid Lugol's solution ( $1 \%$ final concentration) and settled for $48 \mathrm{~h}$ in settling chambers (Utermöhl 1958). Ciliates were divided into size classes of $<25$ and $>25 \mu \mathrm{m}$, whereas phytoplankters were mostly determined to genus level with an inverted microscope (Leica Leitz DM IL, 10× oculars, $25 \times$ and $40 \times$ objectives). At least 400 units of each taxon were counted per cuvette, but all units per cuvette were counted when less than 400 units of the taxon were present in the sample.

Statistical analysis. Repeated measures ANOVA was used to reveal the difference between chlorophyll a concentrations, and numbers of bacteria and ciliates in the plankton communities treated with cyanobacterial filtrates and the control medium. Additionally, 1-way ANOVA was applied to find out whether there was a difference between the cell numbers of each phytoplankton taxon, treated with the 3 cyanobacterial filtrates and the control, on the last day of the experiment. The Tukey's HSD post hoc test was used after all analyses to find out which treatments had an effect that differed from the control. If the treatments differed according to either ANOVA ( $p<0.05)$, only the Tukey HSD results are indicated. The data were tested for normality and homogeneity of variances. ANOVAs were performed using the software SPSS 10.0.7 for Windows.
To analyse the general community changes caused by the cyanobacterial filtrates, based on the cell numbers of different phytoplankton taxa and ciliates, we used species-dependent multivariate techniques of the PRIMER (v5) package (Clarke \& Warwick 2001): hierarchical clustering, analysis of similarity (ANOSIM), and similarity percentages (SIMPER). For hierarchical clustering, the distances between samples were calculated using the Bray-Curtis dissimilarity measure, and the tree was inferred from these distances using average linkage. ANOSIM is based on a simple non-parametric permutation procedure applied to the (rank) similarity matrix underlying the ordination or classification of samples (Clarke \& Warwick 2001). SIMPER identifies the species responsible for particular aspects of the multivariate picture, by disaggregating the similarities obtained from the similarity matrix. The average dissimilarity between all pairs of inter-group samples is first computed, and then the average is divided into separate contributions from each species to the average dissimilarity (Clarke \& Warwick 2001).

\section{RESULTS}

\section{Chlorophyll $a$ and phytoplankton}

The chlorophyll a content of the experimental units remained relatively steady throughout the experiment, irrespective of their treatment with cyanobacterial filtrates or the control medium (Fig. 1). Towards the end of the experiment, the chlorophyll a concentration in the bottles treated with Aphanizomenon sp. filtrate and the control medium decreased slightly, compared

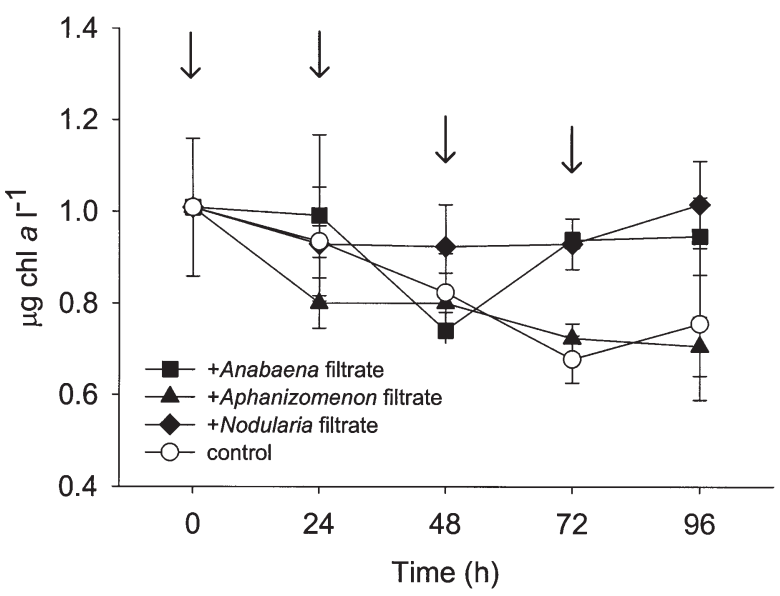

Fig. 1. Chlorophyll a concentration ( $\mu \mathrm{g} \mathrm{chl} \mathrm{a} \mathrm{l}^{-1}$ ) of the phytoplankton community, treated with cell-free filtrates of Anabaena sp., Aphanizomenon sp. and Nodularia spumigena, as well as the control medium $(\mathrm{n}=3$, mean $\pm \mathrm{SD})$. Arrows indicate filtrate addition 
Table 1. Mean concentrations (counting units $\mathrm{l}^{-1}$ ) of phytoplankton taxa in a natural Baltic Sea community in treatments with added cyanobacterial filtrates and in controls $(n=3$, mean $\pm \mathrm{SD})$, at the beginning $(0 \mathrm{~h})$ and the end $(96 \mathrm{~h})$ of the experiment

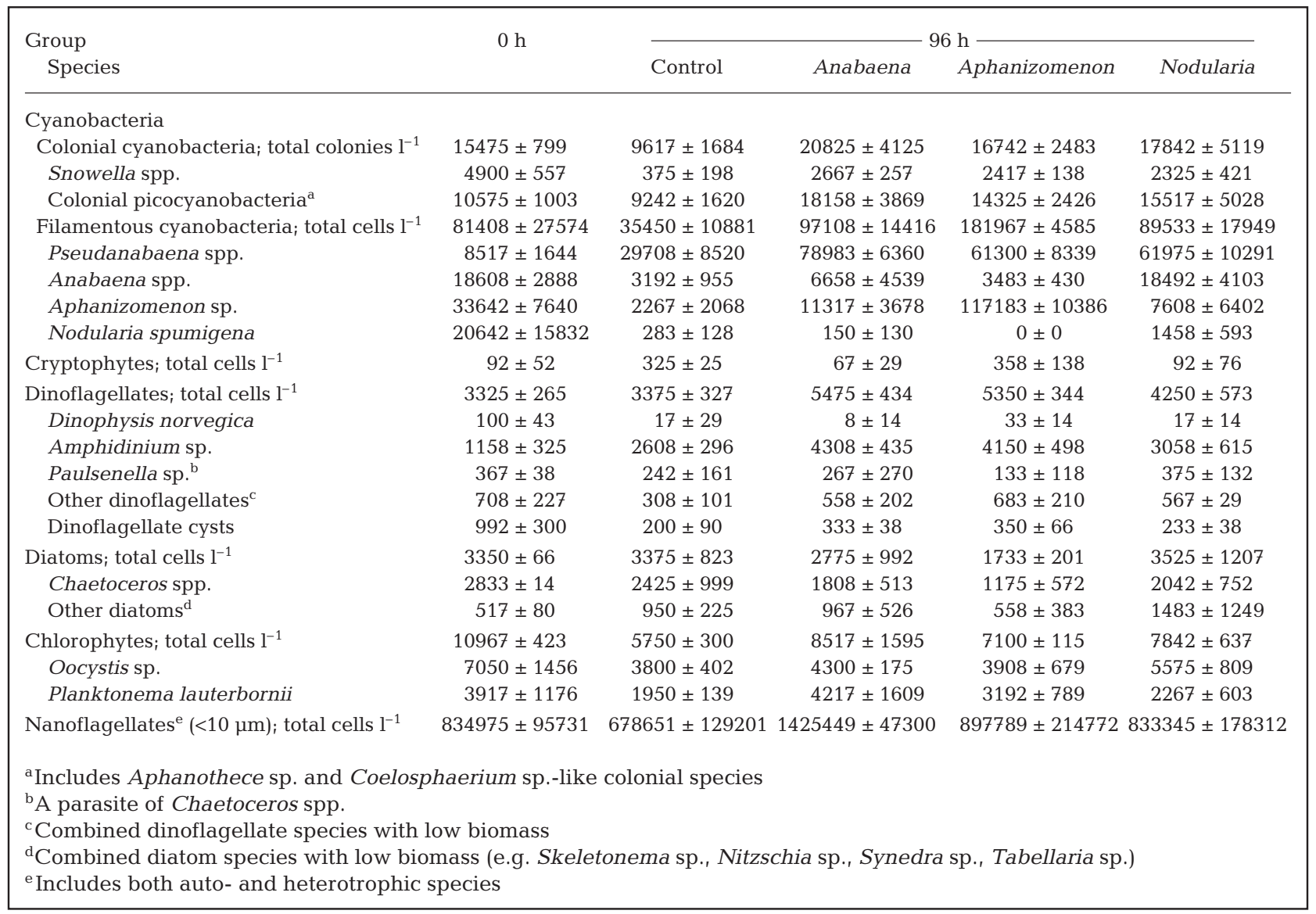

with the ones treated with Nodularia spumigena and Anabaena sp. filtrates, but these differences were statistically non-significant (repeated measures ANOVA, $F_{3,8}=5.61, \mathrm{p}=0.023$; Tukey HSD, $\left.\mathrm{p}>0.05\right)$.

The phytoplankton community was originally composed of various species of cyanobacteria, cryptophytes, dinoflagellates, diatoms, chlorophytes and nanoflagellates (Table 1). Although the cell numbers of many groups tended to decrease throughout the experiment in all treatments, including the control, all major groups present at the beginning were also present after the experiment in all treatments. Only Nodularia spumigena was eliminated in the Aphanizomenon sp. treatment. The effects of cyanobacterial filtrate additions on the different phytoplankton taxa, compared with the control, are listed in Table 2. In several cases, treatment with cyanobacterial filtrates stimulated other cyanobacteria in the community: the numbers of Snowella spp. and Pseudanabaena spp. were significantly higher in all cyanobacterial treatments than in the control (Tukey HSD, p < 0.01); the addition of $N$. spumigena filtrate significantly in- creased the numbers of both $N$. spumigena and Anabaena spp. (Tukey HSD, p < 0.01); and Aphanizomenon sp. filtrate caused an over 50-fold increase in the cell numbers of Aphanizomenon sp. in the community, compared with the control (Tukey HSD, $\mathrm{p}=0.000$; Table 1). The only group that was negatively affected by the cyanobacterial filtrates was cryptophytes. Cryptophytes were inhibited by Anabaena sp. and $N$. spumigena (Tukey HSD, p < 0.04). The heterotrophic dinoflagellate Amphidinium sp. was stimulated by Anabaena sp. and Aphanizomenon sp. (Tukey HSD, p < 0.02), but no other dinoflagellates, nor diatoms, were significantly affected. The growth of the chlorophyte Oocystis sp. was enhanced by $N$. spumigena (Tukey HSD, p = 0.022), and Anabaena sp. had a stimulatory effect on nanoflagellates (Tukey HSD, $p=0.002$ ). Considering the effects of cyanobacterial filtrates within each major phytoplankton group, they were consistent, i.e. the effects on the species within each group only varied from stimulation or inhibition to null effect, and thus there was no group which would have been both positively and negatively affected (Table 2). 
The hierarchical cluster analysis (Fig. 2) revealed that the different treatments were able to generate plankton communities different from both the original community $(0 \mathrm{~h})$ and from each other; in the $96 \mathrm{~h}$ cluster, the cyanobacterial filtrate treatments formed a cluster separated from the control, suggesting that the filtrate treatments caused a different community development than without the influence of filtrates. Between the filtrate treatments, the effect of Aphanizomenon sp. differed from the effects of Anabaena sp. and Nodularia spumigena, which were clustered together. The difference between all treatments was significant (ANOSIM R $=0.957, \mathrm{p}=0.001$ ), and a pairwise comparison showed that all treatments were very separated $(R=1$, with a significance level of $10 \%$, which is the highest possible significance for this number of treatments and replicates), except for $N$. spumigena and Anabaena sp. treatments that were less separated $(\mathrm{R}=0.74, \mathrm{p} \leq 0.1)$. By SIMPER, this difference was found to be mostly due to the general effect of cyanobacterial filtrates on all taxa, and not to a strong effect on any single taxon, since 14 to 15 taxa were needed to explain $90 \%$ of the dissimilarities found. The species contributing most to the dissimilarities between the treatments were: (1) between N. spumigena and Anabaena sp., flagellates (13.2\%) and N. spumi-

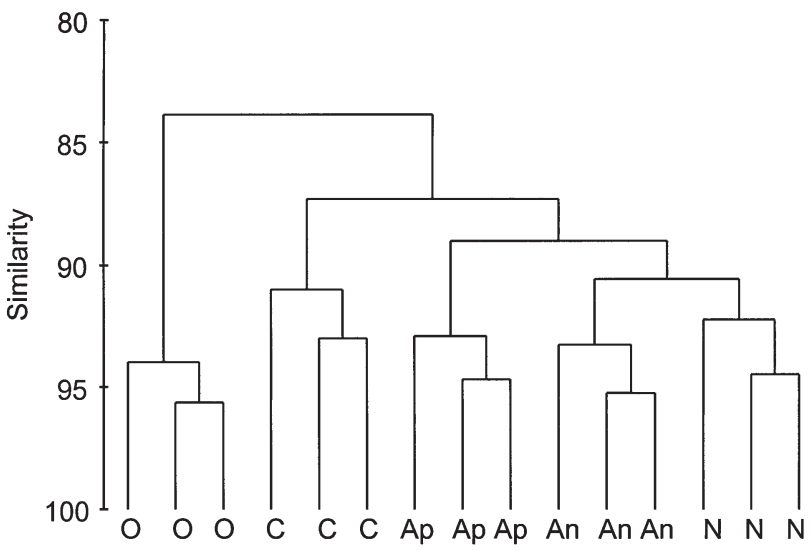

Fig. 2. Hierarchical cluster analysis of the plankton communities at 0 and $96 \mathrm{~h}$. O: original community at $0 \mathrm{~h}_{i} \mathrm{C}$ : control at $96 \mathrm{~h}_{i}$ Ap: Aphanizomenon sp. filtrate treatment at $96 \mathrm{~h}_{i}$ An: Anabaena sp. filtrate treatment at $96 \mathrm{~h} ; \mathrm{N}$ : Nodularia spumigena filtrate treatment at $96 \mathrm{~h}$

gena $(10.6 \%) ;(2)$ between N. spumigena and Aphanizomenon sp., Aphanizomenon sp. (23.5\%) and N. spumigena (14.7\%); and (3) between Anabaena sp. and Aphanizomenon sp., Aphanizomenon sp. (22.6\%) and flagellates $(10.6 \%)$.
Table 2. Statistically significant $(p<0.05)$ effects of cyanobacterial filtrates on phytoplankton taxa, compared with the control, as determined by 1-way ANOVA. +: stimulatory; -: inhibitory; 0: nonsignificant effect

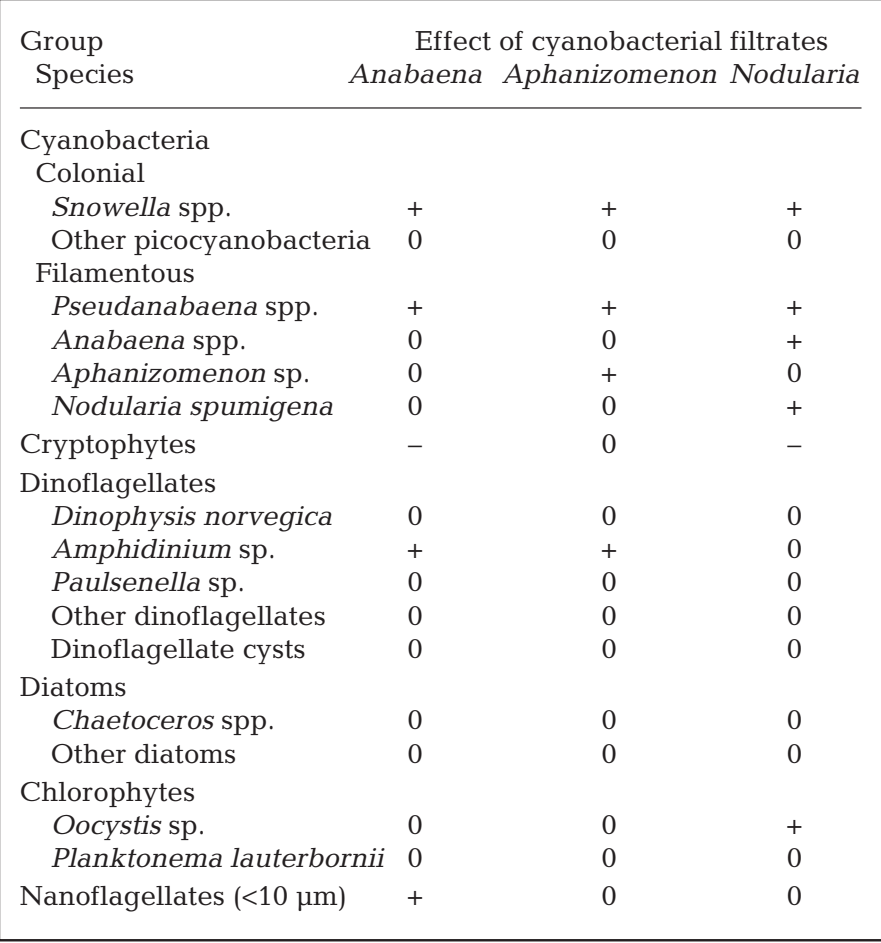

\section{Bacterial abundance}

The bacterial numbers increased steadily from ca. $1.1 \times 10^{6}$ to $1.6 \times 10^{6} \mathrm{ml}^{-1}$, when the community was treated with the control medium (Fig. 3). In the treatments with cyanobacterial filtrates, however, bacterial abundance first increased ca. 3-fold compared to the control, and then decreased gradually, reaching the control level on the last day of the experiment. In the community treated with Nodularia spumigena filtrate, numbers of bacteria were even lower than in the control on the last day (Fig. 3). The overall effects of all cyanobacterial filtrates on the development of the bacterial abundance thus significantly differed from the control (Tukey HSD, $\mathrm{p}<0.001)$.

\section{Ciliate abundance}

The development of ciliate numbers followed a similar pattern, whether treated with the cyanobacterial filtrates or the control medium (Fig. 4), the only exception being the short-time stimulation of small $(<25 \mu \mathrm{m})$ ciliates by Anabaena sp. filtrate at the beginning of the experiment (Fig. 4A). Otherwise, the numbers of 


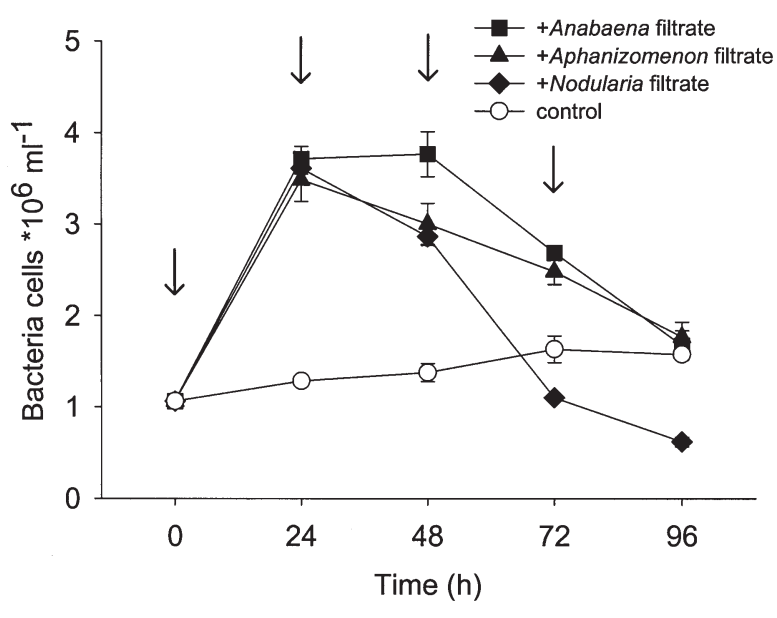

Fig. 3. Cell numbers of bacteria $\left(\times 10^{6} \mathrm{ml}^{-1}\right)$ in the communities treated with cell-free filtrates of Anabaena sp., Aphanizomenon sp. and Nodularia spumigena, as well as the control medium $(n=3$, mean $\pm S D)$. Arrows indicate filtrate addition
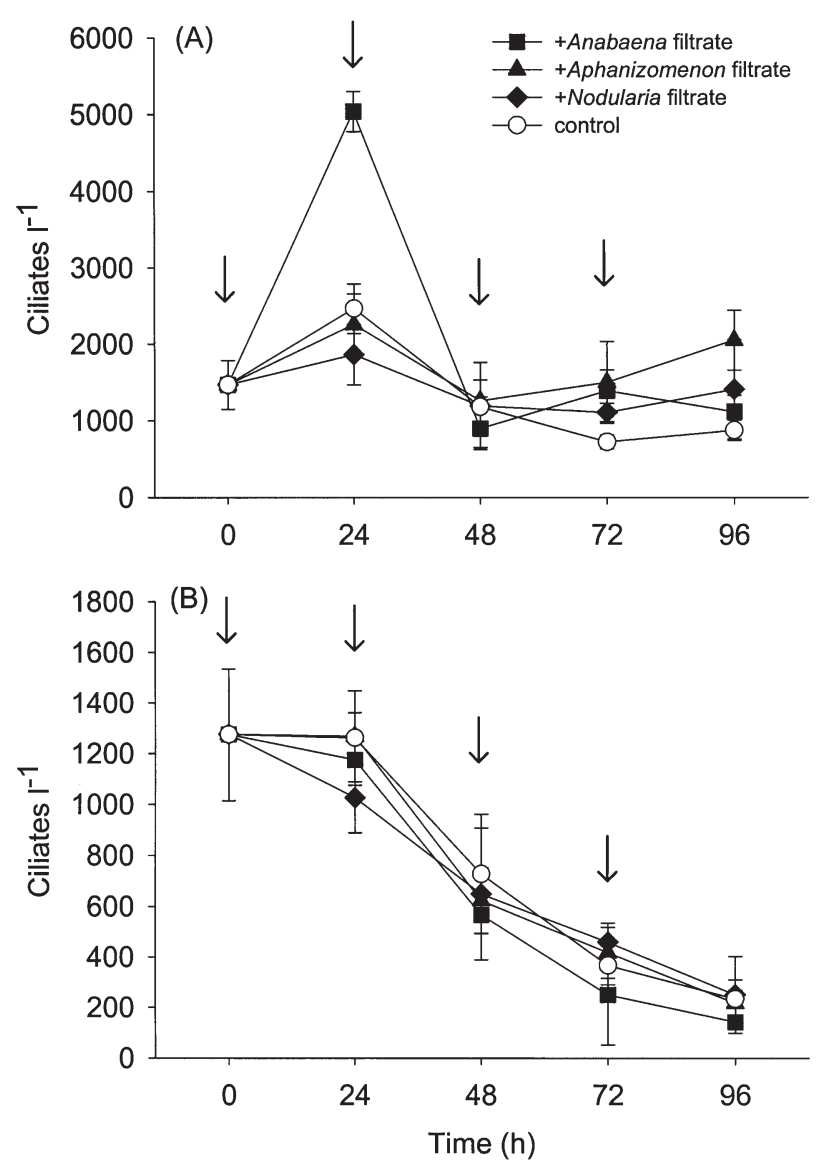

Fig. 4. Abundance of ciliates (ind. $\mathrm{l}^{-1}$ ) of $(\mathrm{A})<25 \mu \mathrm{m}$ and (B) $>25 \mu \mathrm{m}$ in the communities treated with cell-free filtrates of Anabaena sp., Aphanizomenon sp. and Nodularia spumigena, as well as the control medium $(\mathrm{n}=3$, mean $\pm \mathrm{SD})$. Arrows indicate filtrate addition small ciliates remained approximately the same throughout the experiment, although in the end, they were slightly stimulated by the filtrate of Aphanizomenon sp. (Fig. $4 \mathrm{~A}_{i}$ Tukey HSD, $\mathrm{p}=0.025$ ). The abundance of large ciliates, on the other hand, decreased steadily throughout the experiment in all treatments, including the control (Fig. 4B).

\section{DISCUSSION}

Our results indicate that cyanobacteria may both stimulate and inhibit natural plankton assemblages, depending on the species present. We used filtrates of cyanobacterial cultures with a biomass representing a thick surface scum of cyanobacteria (cf. Potter et al. 1983). Such events occur in the Baltic Sea during calm and warm late summer conditions (Kononen et al. 1996), and thus plankton communities are occasionally exposed to the exudates of corresponding cyanobacterial densities.

The tested cyanobacterial filtrates tended to stimulate rather than inhibit many parts of the natural plankton community. Allelopathy includes stimulatory as well as inhibitory biochemical effects, but few scientists involved in allelopathic research have actually reported examples of stimulatory effects (Keating 1977, Rice 1986, Mohamed 2002). In the present study, cyanobacterial exudates had the most pronounced stimulatory effects on the growth of other cyanobacteria. This suggests that the cyanobacteria released some autostimulatory (Monahan \& Trainor 1970) or quorum-sensing compounds (Swift et al. 1994), which accelerated the growth of the same and related species. Alternatively, compounds present in the cyanobacterial filtrates may have been useful to the other cyanobacteria because they may share the same primary metabolism. Cyanobacterial filtrates also promoted the growth of 1 dinoflagellate, an unknown number of nanoflagellates and a chlorophyte, possibly due to some stimulatory allelochemicals. In laboratory experiments with monocultures, cyanobacteria have mostly been found to inhibit chlorophytes and other cyanobacteria (Pushparaj et al. 1999, Gross 2003), but in natural communities, many co-existing species may have developed resistance to the inhibitory metabolites of cyanobacteria, and may even benefit from these or other compounds. In experiments involving species isolated from the same environment, Keating (1987) also found positive effects of cyanobacteria on other cyanobacteria, chlorophytes and motile species. The paucity of reports on positive allelopathy may, therefore, simply reflect the shortage of allelopathic experiments performed with natural communities. 
The inhibition of cryptophytes by Baltic Sea cyanobacteria corresponds well with our previous laboratory tests (Suikkanen et al. 2004), where we demonstrated a strong inhibition of monocultures of the cryptophyte Rhodomonas sp. by all the 3 cyanobacterial strains used in the present study. Not many studies have compared the allelopathic effects of the same species in vitro and in situ, but in the available reports, they have usually supported each other (Keating 1977, 1978, Fistarol et al. 2004). The sensitivity of cryptophytes to allelochemicals from cyanobacteria, dinoflagellates and haptophytes has also been reported by other authors (Infante \& Abella 1985, Rengefors \& Legrand 2001, Granéli \& Johansson 2003b), but the reason why cyanobacteria only inhibited cryptophytes in the community remains unclear. One explanation for this might be the weaker adaptation of cryptophytes to cyanobacterial exudates compared with other phytoplankton groups, as cryptophytes were the least abundant group in the late-summer plankton community used in the present experiment. On the other hand, in monoculture experiments (Suikkanen et al. 2004), the diatom Thalassiosira weissflogii was also inhibited by cyanobacterial filtrates to some extent, although in the present study, no effects on diatoms were observed. Natural community diatoms are probably more resistant to cyanobacterial exudates, because of their preexposure to cyanobacteria in nature, compared with the diatoms grown in monocultures without any prior contact with cyanobacteria.

In the control, the abundances of many phytoplankton groups either decreased or remained at the same level throughout the experiment, which was probably due to the substantial daily dilution of the cultures. However, the growth was often positive in the communities treated with cyanobacterial filtrates, but these differences were not reflected in the chlorophyll a contents of the experimental units. There were no observable effects on chlorophyll $a$, despite the stimulation of the cell numbers of most phytoplankton groups in the units treated with cyanobacterial filtrates, compared with the control. This uncoupling might be due to the fact that the phytoplankton taxa that, by cell numbers, were stimulated by the filtrates were either heterotrophic (part of the flagellates) or small-celled (cyanobacteria, Oocystis sp., the autotrophic flagellates), and thus only represented a fraction of the total chlorophyll a concentration, or biomass, in the community. This is a pattern usually observed in disturbed communities, where small, opportunistic species dominate in numbers but not in biomass; contrary to undisturbed communities, dominated by large species with rather few individuals also dominating in biomass (Clarke \& Warwick 2001). The signs of disturbance may be due to the change in the community caused by the cyanobacterial filtrates. These results demonstrate that strong allelopathic effects are not necessary to cause observable changes in plankton communities. Apparently, the similarity of the effects of Nodularia spumigena and Anabaena sp. filtrates was because these 2 species had a generally stronger effect on the community than Aphanizomenon sp. filtrate.

The initial increase in bacterial numbers may have been due to some dissolved organic compounds present in the cyanobacterial filtrates, as bacteria are able to utilise compounds excreted by phytoplankton (Cole 1982). However, after the initial increase, bacterial numbers decreased, although fresh cyanobacterial filtrates were added each day. This may indicate that bacteria were inhibited by some exudates of cyanobacteria, as antibiotic effects have been observed in all the tested cyanobacterial genera (Østensvik et al. 1998, Pushparaj et al. 1999, Mundt et al. 2001). Alternatively, other organisms in the community (e.g. Snowella spp. that were stimulated by all filtrates) could have either outcompeted the bacteria, or eliminated them by their own allelopathic mechanisms. The bacteria may also have been grazed by the heterotrophic nano- and dinoflagellates, which therefore increased in numbers in the communities treated with the cyanobacterial filtrates. However, the flagellates only increased in communities treated with Anabaena sp. and Aphanizomenon sp. filtrates, whereas the bacteria were reduced in all filtrate treatments, and especially in the Nodularia spumigena treatment. The ultimate reason for the bacterial decline could also be a combination of the mechanisms mentioned above. Grazing by ciliates is unlikely the cause of the bacterial reduction, as ciliate abundances either remained more or less constant, or decreased throughout the experiment, with no clear differences between the filtrate treatments and the control.

The tested cyanobacteria did not seem to produce any substances toxic to ciliates. In other natural community experiments, ciliates have been inhibited by e.g. the haptophytes Chrysochromulina polylepis and Prymnesium parvum, and the dinoflagellate Alexandrium tamarense (Nielsen et al. 1990, Fistarol et al. 2003, 2004, Granéli \& Johansson 2003a). Direct negative effects of cyanobacteria on ciliates have, however, not been demonstrated (Engström-Öst et al. 2002). The most common ciliates in the Baltic Sea are probably unable to feed on filamentous cyanobacteria due to their large size (Kivi \& Setälä 1995), and thus cyanobacteria may not need a chemical defence against ciliate grazers.

Although the filtration was done gently, in order to prevent breaking the majority of the cyanobacterial cells, the culture filtrates probably contained dissolved organic compounds (other than allelochemi- 
cals), which were not present in the control medium. As the aim of the present study was to investigate the overall community changes possibly caused by cyanobacterial blooms in natural microplankton communities, we do not know what specific organic compounds were responsible for the observed effects. In other studies using the same cyanobacterial strains (Suikkanen et al. 2004, and S. Suikkanen unpubl. data), the compound responsible for the allelopathic effects in Nodularia spumigena was unlikely to be nodularin. It is possible that the dissolved organic carbon and/or other compounds stimulated organisms capable of heterotrophic or mixotrophic nutrition, as the cultures were grown at a limiting irradiance. Although such abilities have been detected in most groups present in the community (Granéli et al. 1999), only some of them were significantly stimulated by the filtrate additions. In addition, part of the effects found may only be indirectly due to compounds excreted by the cyanobacteria; e.g. bacteria, while degrading dissolved organic matter originating from the filtrates, may have released compounds stimulating phytoplankton growth, compared with the control with less bacteria.

Cyanobacterial blooms have actually been observed to support active microbial food webs by attracting a wide range of heterotrophic organisms (Hoppe 1981, Engström-Öst et al. 2002, Koski et al. 2002), which has been attributed to the leakage of dissolved organic compounds from cyanobacterial cells to the surrounding heterotrophic bacterial communities and their grazers. Although the effects of mesozooplankton grazers were eliminated in the present study, the complex interactions between the various microplankton organisms in the community make it difficult to draw definite conclusions about the direct and indirect causes of the observed effects. It is, however, possible that allelopathic effects, mediated via the excretion of cyanobacterial secondary metabolites, are involved in the observed stimulation of various phytoplankton species. Cyanobacteria may not cause as dramatic growth inhibition of Baltic Sea microplankton as, for example, the haptophyte Prymnesium parvum (Fistarol et al. 2003), but they seem able to reduce the growth of some taxa while increasing others, and thus cause significant changes in the plankton communities. These results agree with our previous suggestion that the ecological role of allelochemicals in Baltic Sea cyanobacteria is to maintain their dominance (Suikkanen et al. 2004). Yet, rather than inhibiting the competitors of cyanobacteria, these compounds seem to act via the stimulation of the same and other species of cyanobacteria in the community, which may further enhance the effects of eutrophication in the Baltic Sea.
Acknowledgements. We thank K. Sivonen for providing the Aphanizomenon sp. Tr183 strain, and C. Esplund-Lindquist, P. Salomon and C. Legrand for assistance in the laboratory and in the field. We are grateful to J. Engström-Öst and M. Viitasalo for valuable comments on the manuscript. S.S. was financed by the Nordic Academy for Advanced Study (NorFA), University of Helsinki, and the Maj and Tor Nessling Foundation. G.O.F. thanks the Brazilian National Research Council (CNPq) for her PhD grant (process 200384/00-7). Financial support was also provided by the European Commission FATE project (contract holder E.G., EC grant EVK3CT01-00055), as part of the EC EUROHAB cluster.

\section{LITERATURE CITED}

Christoffersen K (1996) Ecological implications of cyanobacterial toxins in aquatic food webs. Phycologia 35(6 Suppl): $42-50$

Clarke KR, Warwick RM (2001) Change in marine communities: an approach to statistical analysis and interpretation, 2nd edn. PRIMER-E, Plymouth

Cole JJ (1982) Interactions between bacteria and algae in aquatic ecosystems. Annu Rev Ecol Syst 13:291-314

del Giorgio PA, Bird DF, Prairie YT, Planas D (1996) Flow cytometric determination of bacterial abundance in lake plankton with the green nucleic acid stain SYTO 13. Limnol Oceanogr 41:783-789

Engström-Öst J, Koski M, Schmidt K, Viitasalo M, Jónasdóttir SH, Kokkonen M, Repka S, Sivonen K (2002) Effects of toxic cyanobacteria on a plankton assemblage: community development during decay of Nodularia spumigena. Mar Ecol Prog Ser 232:1-14

Finni T, Kononen K, Olsonen R, Wallström K (2001) The history of cyanobacterial blooms in the Baltic Sea. Ambio 30: 172-178

Fistarol GO, Legrand C, Granéli E (2003) Allelopathic effect of Prymnesium parvum on a natural plankton community. Mar Ecol Prog Ser 255:115-125

Fistarol GO, Legrand C, Selander E, Hummert C, Stolte W, Granéli E (2004) Allelopathy in Alexandrium spp.: effect on a natural plankton community and on algal monocultures. Aquat Microb Ecol 35:45-56

Granéli E, Johansson N (2003a) Effects of the toxic haptophyte Prymnesium parvum on the survival and feeding of a ciliate: the influence of different nutrient conditions. Mar Ecol Prog Ser 254:49-56

Granéli E, Johansson N (2003b) Increase in the production of allelopathic substances by Prymnesium parvum cells grown under N- or P-deficient conditions. Harmful Algae 2:135-145

Granéli E, Carlsson P, Legrand C (1999) The role of C, N and $\mathrm{P}$ in dissolved and particulate organic matter as a nutrient source for phytoplankton growth, including toxic species. Aquat Ecol 33:17-27

Gross EM (2003) Allelopathy of aquatic autotrophs. Crit Rev Plant Sci 22:313-339

Guillard RL (1975) Culture of phytoplankton for feeding marine invertebrates. In: Smith WL, Chanley MH (eds) Culture of marine invertebrate animals. Plenum Press, New York, p 29-60

Hoppe HG (1981) Blue-green algae agglomeration in surface water: a microbiotope of high bacterial activity. Kiel Meeresforsch Sonderh 5:291-303

Infante A, Abella SEB (1985) Inhibition of Daphnia by Oscillatoria in Lake Washington. Limnol Oceanogr 30:1046-1052 Jespersen AM, Christoffersen K (1987) Measurements of 
chlorophyll a from phytoplankton using ethanol as extraction solvent. Arch Hydrobiol 109:445-454

Kahru M, Horstmann U, Rud O (1994) Satellite detection of increased cyanobacteria blooms in the Baltic Sea: natural fluctuation or ecosystem change? Ambio 23:469-472

Keating KI (1977) Allelopathic influence on blue-green bloom sequence in a eutrophic lake. Science 196:885-887

Keating KI (1978) Blue-green algal inhibition of diatom growth: transition from mesotrophic to eutrophic community structure. Science 199:971-973

Keating KI (1987) Exploring allelochemistry in aquatic systems. In: Waller GR (ed) Allelochemicals: role in agriculture and forestry. American Chemical Society, Washington, DC, p 136-146

Kivi K, Setälä O (1995) Simultaneous measurement of food particle selection and clearance rates of planktonic oligotrich ciliates (Ciliophora: Oligotrichina). Mar Ecol Prog Ser 119:125-137

Kononen K, Kuparinen J, Mäkelä K, Laanemets J, Pavelson J, Nõmmann S (1996) Initiation of cyanobacterial blooms in a frontal region at the entrance to the Gulf of Finland, Baltic Sea. Limnol Oceanogr 41:98-112

Koski M, Schmidt K, Engström-Öst J, Viitasalo M, Jónasdóttir SH, Repka S, Sivonen K (2002) Calanoid copepods feed and produce eggs in the presence of toxic cyanobacteria Nodularia spumigena. Limnol Oceanogr 47:878-885

Landsberg JH (2002) The effects of harmful algal blooms on aquatic organisms. Rev Fish Sci 10:113-390

Legrand C, Rengefors K, Fistarol GO, Granéli E (2003) Allelopathy in phytoplankton-biochemical, ecological, and evolutionary aspects. Phycologia 42:406-419

Lehtimäki J, Moisander P, Sivonen K, Kononen K (1997) Growth, nitrogen fixation, and nodularin production by two Baltic Sea cyanobacteria. Appl Environ Microbiol 63: 1647-1656

Lindholm T, Eriksson JE, Reinikainen M, Meriluoto JAO (1992) Ecological effects of hepatotoxic cyanobacteria. Environ Toxicol Water Qual 7:87-93

Lyra C, Suomalainen S, Gugger M, Vezie C, Sundman P, Paulin L, Sivonen K (2001) Molecular characterization of planktic cyanobacteria of Anabaena, Aphanizomenon, Microcystis and Planktothrix genera. Int J Syst Evol Microbiol 51:513-526

Editorial responsibility: Otto Kinne (Editor-in-Chief), Oldendorf/Luhe, Germany
MacKinney G (1941) Absorption of light by chlorophyll solutions. J Biol Chem 140:315-322

Mohamed ZA (2002) Allelopathic activity of Spirogyra sp.: stimulating bloom formation and toxin production by Oscillatoria agardhii in some irrigation canals, Egypt. J Plankton Res 24:137-141

Monahan TJ, Trainor FR (1970) Stimulatory properties of filtrate from the green alga, Hormotila blennista. I. Description. J Phycol 6:263-269

Mundt S, Kreitlow S, Nowotny A, Effmert U (2001) Biochemical and pharmacological investigations of selected cyanobacteria. Int J Hyg Environ Health 203:327-334

Nielsen TG, Kiørboe T, Bjørnsen PK (1990) Effects of a Chrysochromulina polylepis subsurface bloom on the planktonic community. Mar Ecol Prog Ser 62:21-35

Østensvik Ø, Skulberg OM, Underdal B, Hormazabal V (1998) Antibacterial properties of extracts from selected planktonic freshwater cyanobacteria - a comparative study of bacterial bioassays. J Appl Microbiol 84:1117-1124

Potter IC, Loneragan NR, Lenanton RCJ, Chrystal PJ (1983) Blue-green algae and fish population changes in a eutrophic estuary. Mar Pollut Bull 14:228-233

Pushparaj B, Pelosi E, Jüttner F (1999) Toxicological analysis of the marine cyanobacterium Nodularia harveyana. J Appl Phycol 10:527-530

Rengefors K, Legrand C (2001) Toxicity in Peridinium aciculiferum-an adaptive strategy to outcompete other winter phytoplankton? Limnol Oceanogr 46:1990-1997

Rice EL (1986) Allelopathic growth stimulation. In: Putnam AR, Tang CS (eds) The science of allelopathy. John Wiley \& Sons, New York, p 23-42

Suikkanen S, Fistarol GO, Granéli E (2004) Allelopathic effects of the Baltic cyanobacteria Nodularia spumigena, Aphanizomenon flos-aquae and Anabaena lemmermannii on algal monocultures. J Exp Mar Biol Ecol 308:85-101

Swift S, Bainton NJ, Winson MK (1994) Gram-negative bacterial communication by $\mathrm{N}$-acyl homoserine lactones: a universal language? Trends Microbiol 2:193-198

Utermöhl H (1958) Zur Vervollkommnung der quantitativen Phytoplankton-Methodik. Mitt Int Verein Limnol 9:1-38

Valderrama JC (1995) Methods of nutrient analysis. In: Hallegraeff GM, Anderson DM, Cembella AD (eds) Manual of harmful marine microalgae. IOC Manuals and Guides 33, UNESCO, Paris, p 251-268

Submitted: May 7, 2004; Accepted: October 19, 2004

Proofs received from author(s): February 4, 2005 